\title{
FRATELI TUTTI: FRATERNIDAD Y AMISTAD SOCIAL
}

\section{Rafael Navarro-Valls}

Universidad Complutense de Madrid

rnavarro@der.ucm.es

Era de prever. La encíclica Fratelli tutti ha resultado moderadamente polémica. Para algunos, es la mejor encíclica social de la Historia. Para otros -menos-, un manifiesto político de alguien que debe ser neutral. Permítaseme acercarme al documento dejando al margen las pasiones y guiándonos por la inteligencia.

En realidad, la encíclica viene juzgándose más por el autor que por el contenido. Francisco no es un híbrido entre Rambo y una estrella de rock. Es algo más modesto: un hombre de 83 años, con fe profunda, amplio corazón y una buena cabeza. Eso sí, asistido con especial intensidad por el Espíritu Santo.

Dicho esto, vayamos a la encíclica. Empezaré por decir que me ha divertido una curiosa coincidencia anecdótica. Cuando el primer poder temporal de la tierra (léase, el presidente de Estados Unidos Donald Trump) se encuentra en cuarentena sufriendo el coronavirus, el primer poder moral del mundo sale a su encuentro con una encíclica en la que la pandemia está muy presente. Probablemente ambos habrán percibido la paradoja y también, seguramente, habrán sonreído.

Recuerdo que, muy poco después de que Francisco fuera elegido obispo de Roma, me preguntaron por los grandes desafíos a los que se enfrentaba el Papa argentino. Enumeré 10. Solamente aquí citaré uno de ellos: "Promover la causa de la paz y la justicia en todo el mundo". Este ha sido su empeño constante desde que asumió la carga del papado y que se refleja en esta encíclica.

Desde luego algunas de las afirmaciones apuntan más a la tierra que al cielo. Lo contrario que se decía del Rey Alfonso X el Sabio: "De tanto mirar al cielo se olvidó de la tierra”. Pero no debe perderse de vista que, después de la Creación, todas las cosas de la tierra tienen reflejos divinos.

Recuerdo que en cierta ocasión Juan Pablo II, hablando con un grupo de periodistas, comentó el "papel político" que dicen desempeñó en la caída del marxismo en los países del Este. San Juan Pablo II matizó que "no se puede ha- 
blar de un papel político en sentido estricto". "La misión del Papa -continuó- es predicar el Evangelio, pero en él se encuentra el hombre y, por tanto, sus derechos humanos". Me parece que este es el sentido que se entrevé en Fratelli tutti.

En rápida sucesión pasan por el lector temas muy variados: la pandemia, la guerra, las sanciones legales, la especulación financiera, los muros entre personas, el nacionalismo, el populismo, la pena de muerte, la Shoah, la Organización de Naciones Unidas, la política, el anverso y el reverso de las religiones, y un largo etcétera. Toda una serie de cuestiones que hurgan en las grandes cicatrices de la civilización moderna y a las que ofrece soluciones concretas para cerrarlas.

Vayamos a algunos de los temas más polémicos, comenzando por la política. La actual política -según el Papa- basada exclusivamente en el mercado o el populismo no resuelve la injusticia; al contrario, genera nuevas formas de violencia que amenazan el tejido social. La política que patrocina Francisco es la que dice no "a la corrupción, a la ineficacia, al mal uso del poder o a la falta de respeto a las leyes". Una política popularista (no populista) centrada sobre la dignidad humana, no sobre el beneficio, ya que para Francisco "el mercado por sí mismo no resuelve todo”. Los estragos producidos por la especulación financiera así lo demuestran.

No significa esto -como dicen algunos- que "todas las ganancias son obscenas y todas las pérdidas castas". El propio Francisco lo hacía notar en Evangelii Gaudium, su primera exhortación apostólica (2013) en la que de algún modo repudiaba las "economías angélicas". Para él, el oficio "empresarial" es una "noble tarea". Ante ella, las palabras de Francisco no deben entenderse como las de un enemigo sino, al contrario, como las de un amigo -"ajeno a cualquier interés personal o ideología política" - que desea apartar una mentalidad "individualista, indiferente y egoísta” en aquellos que la poseen. Se trata, en síntesis, de exigir una sólida responsabilidad social a los agentes económicos.

La guerra es un asunto abordado en la encíclica. Aquí Francisco no transige. Es contundente. Para Francisco es muy difícil hablar hoy de guerra justa. De ahí que exclame: "Jamás la guerra". Precisamente porque no es "un fantasma del pasado" sino una amenaza "constante". A causa de las armas nucleares, químicas y biológicas, representa "la negación de todos los derechos". De hecho -según Francisco-, la Tercera Guerra Mundial ha comenzado, aunque sea "a pedazos". Se lee en la encíclica que la eliminación total de las armas nucleares es un "imperativo moral y humanitario". Incluso sugiere algo extremadamente difícil, que se dediquen "los fondos destinados a los armamentos a crear un fondo mundial para eliminar el hambre". 
Podríamos seguir analizando esas concretas cuestiones a las que se refiere la encíclica y que antes enumeramos. Pero, en mi opinión, no las entenderíamos bien sin ir al fondo de la misma.

Desde el subtítulo de la encíclica Fratelli tutti -fraternidad (universal) y amistad social-, ambos polos se ofrecen como el leit motiv del mensaje. Lo dice expresamente el texto: "La fraternidad universal y la amistad social dentro de cada sociedad son dos polos inseparables y coesenciales. Separarlos lleva a una deformación y a una polarización dañina”. Con la fraternidad universal no hay duda: "Todos los seres humanos somos hermanos y hermanas". Con palabras del Documento sobre la fraternidad humana firmado en Abu Dabi (febrero de 2019): "Dios ha creado todos los seres humanos iguales en los derechos, en los deberes y en la dignidad, y los ha llamado a convivir como hermanos entre ellos".

A la fraternidad universal se opone una grave enfermedad: "El individualismo radical es el virus más difícil de vencer", tal como se manifiesta en las "sombras de un mundo cerrado". Por eso, subraya, "mientras nuestro sistema económico y social produzca una sola víctima y haya una sola persona descartada, no habrá una fiesta de fraternidad universal".

Vayamos al otro polo: la amistad social. Se describe en la encíclica diciendo que el amor que se extiende más allá de las fronteras tiene su base imprescindible en el amor a la propia ciudad o país. "Cuando es genuina, esta amistad social dentro de una sociedad es una condición de posibilidad de una verdadera apertura universal”.

En fin, subraya Francisco que fomentar la amistad social precisa la apertura y el diálogo. Las religiones, cuando son acordes a esta verdad profunda de la dignidad humana y la promueven a través del diálogo entre las culturas y la búsqueda de la paz, se sitúan "al servicio de la fraternidad en el mundo". La propuesta creyente aporta "razones sólidas y estables para la llamada a la fraternidad".

El fundamento que une y mantiene viva y fecunda esa polaridad es claro: "Hay un reconocimiento básico, esencial para caminar hacia la amistad social y la fraternidad universal: percibir cuánto vale un ser humano, cuánto vale una persona, siempre y en cualquier circunstancia”.

Cabe concluir que esta extensa encíclica parece el testamento espiritual de Francisco. Recoge en ella el conjunto de sus mensajes anteriores. Por ello, requiere un estudio pausado si queremos entender el papel que este Papa está desempeñando en la Historia. 
Rafael Navarro-Valls | Fratelli tutti: fraternidad y amistad social

El presente es un artículo que se publicó el día 8 de octubre de 2020 en el diario El Mundo, en el cual su autor, Rafael Navarro-Valls, analiza algunos de los aspectos más destacados de la tercera encíclica del papa Francisco. 